\title{
International legislation on nutrition and health claims
}

Citation for published version (APA):

de Boer, A., \& Bast, A. (2015). International legislation on nutrition and health claims. Food Policy, 55, 6170. https://doi.org/10.1016/j.foodpol.2015.06.002

Document status and date:

Published: 01/08/2015

DOI:

10.1016/j.foodpol.2015.06.002

Document Version:

Publisher's PDF, also known as Version of record

Document license:

Taverne

\section{Please check the document version of this publication:}

- A submitted manuscript is the version of the article upon submission and before peer-review. There can be important differences between the submitted version and the official published version of record.

People interested in the research are advised to contact the author for the final version of the publication, or visit the DOI to the publisher's website.

- The final author version and the galley proof are versions of the publication after peer review.

- The final published version features the final layout of the paper including the volume, issue and page numbers.

Link to publication

\footnotetext{
General rights rights.

- You may freely distribute the URL identifying the publication in the public portal. please follow below link for the End User Agreement:

www.umlib.nl/taverne-license

Take down policy

If you believe that this document breaches copyright please contact us at:

repository@maastrichtuniversity.nl

providing details and we will investigate your claim.
}

Copyright and moral rights for the publications made accessible in the public portal are retained by the authors and/or other copyright owners and it is a condition of accessing publications that users recognise and abide by the legal requirements associated with these

- Users may download and print one copy of any publication from the public portal for the purpose of private study or research.

- You may not further distribute the material or use it for any profit-making activity or commercial gain

If the publication is distributed under the terms of Article $25 \mathrm{fa}$ of the Dutch Copyright Act, indicated by the "Taverne" license above, 
View Point

\title{
International legislation on nutrition and health claims
}

\author{
Alie de Boer*, Aalt Bast \\ Department of Pharmacology and Toxicology, Faculty of Health Medicine and Life Sciences, Maastricht University, Maastricht, The Netherlands
}

\section{A R T I C L E I N F O}

\section{Article history:}

Received 14 February 2014

Received in revised form 12 May 2015

Accepted 16 June 2015

Available online 3 July 2015

\section{Keywords:}

Food law

Nutrition claims

Health claims

Graded claims

FDA

EFSA

\begin{abstract}
A B S T R A C T
The increasing public interest in dietary health benefits led to the development of different legislative texts on nutrition and health claims worldwide. Following a review of legislation of 28 jurisdictions, three prominent differences were discerned, concerning (i) the labelling of different types of nutrition and health claims and their permission; (ii) variations arising in the (pre-marketing) authorisation procedures; and (iii) the use of the scientific minority opinion in substantiating claims. By discussing these legal differences with findings from literature concerning consumer and industry effects, this review puts these pieces of legislation into a broader perspective. The studied pieces of legislation show critical differences and although various approaches have positive points, no optimal approach to regulate nutrition and health claims has been implemented yet. It would be preferable to permit similar types of claims throughout jurisdictions, permit claims that have a lower probability of misleading consumers e.g. nutrition claims to use emerging evidence and to require pre-marketing approval of claims with higher impact. International harmonisation in these aspects should globally lead to improved pieces of legislation, stimulate industrial efforts in functional foods and enhance consumers' opportunity to use health-enhancing products.
\end{abstract}

() 2015 Elsevier Ltd. All rights reserved.

\section{Introduction}

The increasing public interest in possible health benefits of foods has created an attractive opportunity for the food industry, i.e. developing functional foods. Functional foods are foods which are consumed within a normal dietary pattern, with health-enhancing properties beyond adequate nutritional effects (Diplock et al., 1999; Howlett, 2008; Lalor and Wall, 2011; Moors, 2012). Japan was the first jurisdiction to regulate functional foods and their commercial outings by means of the FOSHU (Foods for Specified Health Use), which was based on research initiated in 1984 on the effects of these foods (Jones et al., 2008; Lalor and Wall, 2011; Ohama et al., 2006). FOSHU described the requirements for scientific substantiation of a claim on the health effect elicited by such a functional food product (Ohama et al., 2006). Currently, several pieces of legislation dealing with nutrition and health claims are enforced throughout the world (Jones et al., 2008).

The international market of functional foods is growing, even though consumers in countries affected by the economic turmoil are less willing to pay premium prices (Euromonitor

\footnotetext{
* Corresponding author at: Department of Pharmacology and Toxicology, Faculty of Health Medicine and Life Sciences, Maastricht University, P.O. Box 616, 6200 MD Maastricht, The Netherlands. Tel.: +31 433882106 .

E-mail address: a.deboer@maastrichtuniversity.nl (A. de Boer).
}

International, 2015a). The growth of the market is higher in countries less affected by this economic turmoil: the United States of America (USA) reported a market growth of functional foods of $0.9 \%$ over the years 2008-2013, where the growth reported in China was $21.1 \%, 21.3 \%$ in Argentina and even $33.8 \%$ in Venezuela in the same period (Euromonitor International, 2015b). Growth forecasts show that the market is expected to grow in almost all countries in the upcoming years, but are most optimistic for Asia, varying from an expected growth of $0.6 \%$ in Japan up to $13.4 \%$ in China (Euromonitor International, 2015c). Still, the market share of functional foods is rather small in numerous countries (Euromonitor International, 2015b). This increases the interest of the food industry to operate on an international level. However, global variations in legislative requirements on nutrition and health claims complicate the marketing of functional foods across jurisdictions (Aschemann-Witzel and Hamm, 2010; Jew et al., 2008; Jones et al., 2008; Kwak and Jukes, 2000; Lalor and Wall, 2013; Richardson et al., 2003).

This paper reviews current international pieces of legislation on nutrition and health claims in an attempt to show the diverse approaches and to envision ways to optimise procedures from a scientific perspective. The similarities and differences in required scientific substantiation and their review processes can be found elsewhere (e.g. (Jew et al., 2008; Malla et al., 2013)) and will therefore not be discussed thoroughly in this paper. 


\section{Methods}

The jurisdictions described in the 2004 WHO report on the global regulatory environment of nutrition labels and health claims were the starting point of this review (Hawkes, 2004). The 22 jurisdictions from this report on which English information was available were included in this research and an additional six jurisdictions were identified where information on nutrition and health claim legislation was available in English.

Information from various sources was used to identify permitted and prohibited types of claims, as well as upon the authorisation procedure and the norm of scientific substantiation for claims by studying legislation of the various jurisdictions and scientific literature describing legislation concerning nutrition and health claims in different jurisdictions. Guidance documents from regulatory bodies dealing with nutrition and health claims were studied. Documents describing the interpretation of pieces of legislation were critically assessed to provide additional information on various jurisdictions. This created the opportunity to compare the different pieces of legislation upon nutrition and health claims and their surrounding procedures.

\section{Results}

Where the 28 identified jurisdictions are all seen to regulate nutrition and health claims, variations were found in the different pieces of legislation: (i) the different types of nutrition and health claims are described; (ii) whether or not authorisation is required and which shape it takes; and (iii) the possibility of using emerging scientific evidence.

\section{Types of claims}

The 'Guidelines for Use of Nutrition and Health Claims' published by the Codex Alimentarius Committee defines two types of claims, viz. nutrition claims and health claims (Codex Committee on Food Labelling, 2013). Nutrition claims are defined as 'any representation which states, suggests, or implies that a food has particular nutritional properties'. These claims include three categories of claims: (i) nutrient content claims, describing the level of a nutrient contained in a food (e.g. 'contains calcium'); (ii) nutrient comparative claims, which compare the nutrient and/or energy levels of two or more foods (e.g. 'light'); and (iii) non-addition claims, describing that a specific ingredient has not been added to a food (e.g. 'fat free') (Codex Committee on Food Labelling, 2013).

The Codex guidelines define health claims as "any representation that states, suggests, or implies that a relationship exists between a food or a constituent of that food and health", including three types of claims: (i) nutrient function claims, describing the physiological role of the nutrient in growth, development and normal functions of the body (e.g. 'vitamin C contributes to the normal function of the immune system'); (ii) other function claims, emphasising specific beneficial effects of the consumption of foods or their constituents, relating to a positive contribution to health or the improvement of a function or to modifying or preserving health ('cocoa flavanols help maintain the elasticity of blood vessels, which contributes to normal blood flow'); and (iii) claims on reduction of disease risk, which relate the consumption of a food or food constituent, in the context of the total diet, to the reduced risk of developing a disease or health-related condition ('Calcium helps to reduce the loss of bone mineral in post-menopausal women. Low bone mineral density is a risk factor for osteoporotic bone fractures.') (Codex Committee on Food Labelling, 2013).

Although the studied jurisdictions label the types of claims differently, all claims can be categorised within these six categories.
Differences arise between the types of claims permitted for use within the various jurisdictions, as depicted in Table 1 . Since most pieces of legislation do not further specify the specific types of nutrition claims permitted or prohibited, only the full category is presented in the table.

In all reviewed jurisdictions, nutrition claims are officially permitted for use (Agri-Food and Veterinary Authority of Singapore 2015; Bureau of Food and Drugs, 1984; Centre for Food Safety, 2008; Consejo de Ministros de Integración Económica Centroamericana, 2012; Department of Health, 2010; European Parliament and Council of the European Union, 2006; Food and Drug Administration Taiwan, 2012; Food and Drug Administration, 2013; Food Standards Australia New Zealand, 2014; Giudice, 2013; Global Agricultural Information Network, 2011a; Government of Canada, 2013; Malla et al., 2013; Ministerio de la Protección Social, 2008; Ministerio de Salud, 2011; Ministry of Agriculture, Agricultural and Livestock Service, 2006; Ministry of Food and Drug Safety, 2011; Ministry of Health, 2013a, 2013b, 2001; National Agency for Food and Drug Administration and Control, 2005; National Agency of Drug and Food Control, 2011; Ohama et al., 2006; People's Republic of China, 2011; Republic of Ecuador, 2011a; Secretaría de Economia, 2010; Zawistowski, 2011). Generally this entails the use of both nutrient content claims and nutrient comparative claims, only legislation in Chile, Japan and Taiwan does not specifically address the use of nutrient comparative claims (Malla et al., 2013; Ministry of Agriculture, Agricultural and Livestock Service, 2006; Ohama et al., 2006; Zawistowski, 2011).

The use of nutrient function claims is allowed in almost all evaluated jurisdictions (Agri-Food and Veterinary Authority of Singapore, 2015; Bureau of Food and Drugs, 1984; Centre for Food Safety, 2008; Chan, 2011; Consejo de Ministros de Integración Económica Centroamericana, 2012; da Silveira et al., 2009; Department of Health, 2010; European Parliament and Council of the European Union, 2006; Food and Drug Administration Taiwan, 2012; Food and Drug Administration, 2013; Food Standards Australia New Zealand, 2014; Global Agricultural Information Network, 2011a; Government of Canada, 2013; Malla et al., 2013; Ministerio de la Protección Social, 2008; Ministerio de Salud, 2011; Ministry of Agriculture, Agricultural and Livestock Service, 2006; Ministry of Food and Drug Safety, 2011; Ministry of Health Labour and Welfare, Japan, 2015a; Ministry of Health, 2013a, 2013b; National Agency of Drug and Food Control, 2011; Ohama et al., 2006; People's Republic of China, 2011; Republic of Ecuador, 2011b; Secretaría de Economia, 2010; Zawistowski, 2011). Only Brunei Darussalam and Nigeria prohibit the use of nutrient function claims (Ministry of Health, 2001; National Agency for Food and Drug Administration and Control, 2005). In Nigeria food products bearing health claims are regarded and regulated as drugs and therefore claims are not permitted on regular food products (Global Agricultural Information Network, 2012). The legislation in most jurisdictions reviewed, considers nutrient function claims to be health claims, yet they are judged as nutrition claims in Malaysia and Thailand (Malla et al., 2013; Ministry of Health, 2013a; Ministry of Public Health, 1998).

Other or enhanced function claims are prohibited in, Brunei Darussalam, India, Nigeria, South-Africa and Thailand, although the new draft regulation on nutrition and health claims in India does permit these claims (Food Safety and Standards Authority of India, 2012; Gautier, 2012; Ministry of Health, 2001; Ministry of Public Health, 1998; National Agency for Food and Drug Administration and Control, 2005). Legislation in Hong Kong and Vietnam does not specifically describe nor prohibit other or enhanced function claims (Ministry of Health, 2013b; Public Health and Municipal Services Ordinance, 2008). Within the 21 
Table 1

Types of claims permitted or prohibited per jurisdiction.

\begin{tabular}{|c|c|c|c|c|}
\hline \multirow[t]{2}{*}{ Jurisdictiol } & \multirow{2}{*}{$\begin{array}{l}\text { Nutrition } \\
\text { claim }\end{array}$} & \multicolumn{3}{|c|}{ Health claim } \\
\hline & & $\begin{array}{l}\text { Nutrient } \\
\text { function } \\
\text { claim }\end{array}$ & $\begin{array}{l}\text { Other } \\
\text { function } \\
\text { claim }\end{array}$ & $\begin{array}{l}\text { Reduction of } \\
\text { disease risk } \\
\text { claim }\end{array}$ \\
\hline \multicolumn{5}{|l|}{ Argentina } \\
\hline \multicolumn{5}{|c|}{ Australia/New Zealand } \\
\hline \multicolumn{5}{|l|}{ Barbados } \\
\hline \multicolumn{5}{|l|}{ Brazil } \\
\hline \multicolumn{5}{|c|}{ Brunei Darussalam } \\
\hline \multicolumn{5}{|l|}{ Canada } \\
\hline \multicolumn{5}{|c|}{ Central America $^{a}$} \\
\hline \multicolumn{5}{|l|}{ Chile } \\
\hline \multicolumn{5}{|l|}{ China } \\
\hline \multicolumn{5}{|l|}{ Colombia } \\
\hline \multicolumn{5}{|l|}{ Ecuador } \\
\hline \multicolumn{5}{|c|}{ European Union } \\
\hline Hong Kon & & & 10 & \\
\hline \multicolumn{5}{|l|}{ India } \\
\hline \multicolumn{5}{|l|}{ Indonesia } \\
\hline \multicolumn{5}{|l|}{ Japan } \\
\hline \multicolumn{5}{|l|}{ Malaysia } \\
\hline \multicolumn{5}{|l|}{ Mexico } \\
\hline \multicolumn{5}{|l|}{ Nigeria } \\
\hline \multicolumn{5}{|c|}{ Republic of Korea } \\
\hline \multicolumn{5}{|l|}{ Russia } \\
\hline \multicolumn{5}{|l|}{ Singapore } \\
\hline \multicolumn{5}{|c|}{ South-Africa } \\
\hline \multicolumn{5}{|l|}{ Taiwan } \\
\hline \multicolumn{5}{|l|}{ Thailand } \\
\hline \multicolumn{5}{|c|}{ The Philippines } \\
\hline \multicolumn{5}{|c|}{$\begin{array}{l}\text { United States of } \\
\text { America }\end{array}$} \\
\hline Vietnam & & & $\mathrm{n} / \mathrm{k}$ & $\mathrm{n} / \mathrm{k}$ \\
\hline
\end{tabular}

\footnotetext{
= permitted in legislation.

$=$ prohibited in legislation

$=$ not specified in legislation.

a Including Costa Rica, El Salvador, Guatamala, Honduras, Nicaragua.

b Permitted in draft regulation.

c Regarded as nutrition claim.

${ }^{d}$ Not permitted on food, products with these claims are regulated under drug regulations.
}

other jurisdictions the use of these claims is permitted (Agri-Food and Veterinary Authority of Singapore, 2015; Bureau of Food and Drugs, 1984; Consejo de Ministros de Integración Económica Centroamericana, 2012; da Silveira et al., 2009; European Parliament and Council of the European Union, 2006; Food and Drug Administration Taiwan, 2012; Food and Drug Administration, 2013; Food Standards Australia New Zealand, 2014; Global Agricultural Information Network, 2011a; Government of Canada, 2013; Malla et al., 2013; Ministerio de la Protección Social, 2008; Ministerio de Salud, 2011; Ministry of Agriculture, Agricultural and Livestock Service, 2006; Ministry of Food and Drug Safety, 2010; Ministry of Health Labour and Welfare, Japan, 2015b; Ministry of Health, 2013a; National Agency of Drug and Food Control, 2011; People's Republic of China, 2011; Republic of Ecuador, 2011b; Secretaría de Economia, 2010).

Brunei Darussalam, Hong Kong, India, Malaysia, Mexico, Nigeria, Russia, South-Africa, Taiwan and Thailand prohibit the use of disease risk reduction claims on food products (Centre for Food Safety, 2008; Department of Health, 2010; Food and Drug Administration Taiwan, 2012; Gautier, 2012; Malla et al., 2013; Ministry of Health, 2013a, 2001; Ministry of Public Health, 1998; National Agency for Food and Drug Administration and Control, 2005; Secretaría de Economia, 2010; Zawistowski, 2011). Additionally the draft regulation in India permits the use of these claims, while Vietnamese legislation does not specifically address these types of claims (Food Safety and Standards Authority of India, 2012; Ministry of Health, 2013b). Within thee 17 other jurisdictions using disease risk reduction claim is permitted (Agri-Food and Veterinary Authority of Singapore, 2015; Bureau of Food and Drugs, 1984; Consejo de Ministros de Integración Económica Centroamericana, 2012; da Silveira et al., 2009; European Parliament and Council of the European Union, 2006; Food and Drug Administration, 2013; Food Standards Australia New Zealand, 2014; Global Agricultural Information Network, 2011a; Government of Canada, 2013; Ministerio de la Protección Social, 2008; Ministerio de Salud, 2011; Ministry of Agriculture, Agricultural and Livestock Service, 2006; Ministry of Food and Drug Safety, 2010; Ministry of Health Labour and Welfare, Japan, 2015b; National Agency of Drug and Food Control, 2011; People's Republic of China, 2011; Republic of Ecuador, 2011b).

Canadian legislation goes beyond other pieces of legislation by permitting the use of therapeutic claims after pre-marketing review. These are claims suggesting that the consumption of a nutrient is able to 'treat or mitigate a disease or condition or restore or otherwise modify an existing function' (Malla et al., 2013). Today however no therapeutic claim has been approved for use in Canada (Health Canada, 2015).

\section{Authorisation procedures}

Different authorisation procedures are defined in different jurisdictions (Table 2).

As depicted in Table 2, the authorisation procedure concerning nutrition claims is not explicitly described in most studied jurisdictions. These jurisdictions (except for Brunei Darussalam, Chile, India, Nigeria, Republic of Korea, Russia, Taiwan, the Philippines and Vietnam) list the conditions that nutrition claims have to comply with, but in their pieces of legislation no authorisation procedure for carrying these claims is described (Agri-Food and Veterinary Authority of Singapore, 2015; Baccino, 2012; Centre for Food Safety, 2008; Chan, 2011; Consejo de Ministros de Integración Económica Centroamericana, 2012; Department of Health, 2010; Food Standards Australia New Zealand, 2014; Global Agricultural Information Network, 2011a; Government of Canada, 2013; Malla et al., 2013; Ministerio de la Protección 
Table 2

Authorisation procedures.

\begin{tabular}{|c|c|c|c|c|}
\hline \multirow[t]{2}{*}{ Jurisdiction } & \multirow[t]{2}{*}{ Nutrition claim } & \multicolumn{3}{|l|}{ Health claim } \\
\hline & & Nutrient function claim & Other function claim & Reduction of disease risk claim \\
\hline Argentina & $\mathrm{n} / \mathrm{k}$ & PM & PM & PM \\
\hline Australia/New Zealand & $\mathrm{n} / \mathrm{k}$ & NOT & NOT & PM-N \\
\hline Barbados & $\mathrm{n} / \mathrm{k}$ & PM-N & PM-N & PM-N \\
\hline Brazil & $\mathrm{n} / \mathrm{k}$ & PM & PM & PM \\
\hline Brunei Darussalam & $\mathrm{n} / \mathrm{k}$ & $\mathrm{n} / \mathrm{a}$ & $\mathrm{n} / \mathrm{a}$ & $\mathrm{n} / \mathrm{a}$ \\
\hline Canada & $\mathrm{n} / \mathrm{k}$ & PM-N & PM-N & PM-N \\
\hline Central America $^{a}$ & $\mathrm{n} / \mathrm{k}$ & PM-N & PM-N & PM-N \\
\hline Chile & $\mathrm{n} / \mathrm{k}$ & NN & NN & NN \\
\hline China & NP & NP & PM & $\mathrm{PM}^{\mathrm{b}}$ \\
\hline Colombia & $\mathrm{n} / \mathrm{k}$ & NN & PM-N & PM-N \\
\hline Ecuador & $\mathrm{n} / \mathrm{k}$ & PM-N & PM-N & PM-N \\
\hline European Union & PM-N & PM-N & PM-N & PM-N \\
\hline Hong Kong & $\mathrm{n} / \mathrm{k}$ & $\mathrm{n} / \mathrm{k}$ & $\mathrm{n} / \mathrm{a}$ & $\mathrm{n} / \mathrm{a}$ \\
\hline India & NN & NN & $\mathrm{n} / \mathrm{a}$ & $\mathrm{n} / \mathrm{a}$ \\
\hline Indonesia & PM-N & PM-N & PM-N & PM-N \\
\hline Japan & $\mathrm{n} / \mathrm{k}$ & NN & PM & PM \\
\hline Malaysia & $\mathrm{n} / \mathrm{k}$ & PM-N & PM-N & $\mathrm{n} / \mathrm{a}$ \\
\hline Mexico & $\mathrm{n} / \mathrm{k}$ & $\mathrm{n} / \mathrm{k}$ & $\mathrm{n} / \mathrm{k}$ & $\mathrm{n} / \mathrm{a}$ \\
\hline Nigeria & $\mathrm{n} / \mathrm{k}$ & $\mathrm{n} / \mathrm{a}$ & $\mathrm{n} / \mathrm{a}$ & $\mathrm{n} / \mathrm{a}$ \\
\hline Republic of Korea & $\mathrm{n} / \mathrm{k}$ & PM-N & PM-N & PM-N \\
\hline Russia & $\mathrm{n} / \mathrm{k}$ & PM & PM & $\mathrm{n} / \mathrm{a}$ \\
\hline Singapore & $\mathrm{n} / \mathrm{k}$ & PM-N & PM-N & PM \\
\hline South-Africa & $\mathrm{n} / \mathrm{k}$ & $\mathrm{n} / \mathrm{k}$ & $\mathrm{n} / \mathrm{a}$ & $\mathrm{n} / \mathrm{a}$ \\
\hline Taiwan & $\mathrm{n} / \mathrm{k}$ & NP & NP & $\mathrm{n} / \mathrm{a}$ \\
\hline Thailand & $\mathrm{n} / \mathrm{k}$ & $\mathrm{n} / \mathrm{k}$ & $\mathrm{n} / \mathrm{a}$ & $\mathrm{n} / \mathrm{a}$ \\
\hline The Philippines & $\mathrm{n} / \mathrm{k}$ & $\mathrm{n} / \mathrm{k}$ & $\mathrm{n} / \mathrm{k}$ & $\mathrm{n} / \mathrm{k}$ \\
\hline United States of America & $\mathrm{NP}$ & $\mathrm{NN}^{\mathrm{c}}$ & $\mathrm{NN}^{\mathrm{c}}$ & PM-N \\
\hline Vietnam & $\mathrm{n} / \mathrm{k}$ & $\mathrm{n} / \mathrm{k}$ & $\mathrm{n} / \mathrm{a}$ & $\mathrm{n} / \mathrm{a}$ \\
\hline
\end{tabular}

$\mathrm{NN}$ = explicitly no pre-marketing approval required, scientific substantiation must be available upon request of the regulatory authority.

NOT $=$ pre-marketing notification required for all claims.

$\mathrm{NP}=$ no possibility to include additional claims by companies; various claims have been approved by regulatory authority before marketing.

$\mathrm{PM}=$ pre-marketing approval required for all claims.

$\mathrm{PM}-\mathrm{N}$ = pre-marketing approval required for claims describing new health effects of nutrients.

$\mathrm{n} / \mathrm{a}=$ type of claim prohibited or not described in legislation.

$\mathrm{n} / \mathrm{k}=$ authorisation procedure not defined in legislation.

a Including Costa Rica, El Salvador, Guatamala, Honduras, Nicaragua.

b New claims can only be based on pre-authorised relationships, listed in a register of the SFDA.

c For dietary supplements pre-marketing notification is required for all claims.

Social, 2008; Ministry of Health Labour and Welfare, Japan, 2015c; Ministry of Health, 2013a; Ministry of Public Health, 1998; National Agency of Drug and Food Control, 2011; Republic of Ecuador, 2011a; Secretaría de Economia, 2010; Stringueta et al., 2012). Only legislation in China and the USA list the approved claims, without giving the possibility to request approval of new claims (Food and Drug Administration, 2013; People's Republic of China, 2011). The requirements for previously approved nutrition claims are listed in legislation or registers of the regulatory bodies. In Europe and Indonesia new nutrition claims (claims which not have been approved for use previously) have to obtain pre-marketing approval (European Parliament and Council of the European Union, 2006; National Agency of Drug and Food Control, 2011). Approved nutrient and other function claims are listed in either pieces of legislation or registers of regulatory authorities in Australia/New Zealand, Canada, Central America, Colombia (other function claims only), the EU, Indonesia, Malaysia, Republic of Korea, Singapore and Taiwan (Agri-Food and Veterinary Authority of Singapore, 2015; Consejo de Ministros de Integración Económica Centroamericana, 2012; European Parliament and Council of the European Union, 2006; Food and Drug Administration Taiwan, 2012; Food Standards Australia New Zealand, 2014; Government of Canada, 2013; Ministerio de la Protección Social, 2008; Ministry of Food and Drug Safety, 2010; Ministry of Health, 2013a; National Agency of Drug and Food Control, 2011). These lists do not only describe the conditions the claims have to fulfil, but wording of a claim is also suggested. These registers are often considered as positive lists, outlining approved claims and their specific conditions (Verhagen et al., 2010). In Chile, Ecuador, Hong Kong, Mexico and Thailand, specific conditions for nutrient function claims can be found, but legislation is less explicit upon the suggested wording of claims (Centre for Food Safety, 2008; Ministry of Agriculture, Agricultural and Livestock Service, 2006; Ministry of Public Health, 1998; Republic of Ecuador, 2011b; Secretaría de Economia, 2010). For other function claims such conditions can be found in Chile, Ecuador and Mexico (Ministry of Agriculture, Agricultural and Livestock Service, 2006; Republic of Ecuador, 2011b; Secretaría de Economia, 2010).

Most jurisdictions which use a list of claims require pre-marketing approval by the regulatory authority of claims which are not published on the list (Agri-Food and Veterinary Authority of Singapore, 2015; Consejo de Ministros de Integración Económica Centroamericana, 2012; European Parliament and Council of the European Union, 2006; Government of Canada, 2013; Ministerio de la Protección Social, 2008; Ministry of Food and Drug Safety, 2010; Ministry of Health, 2013a; National Agency of Drug and Food Control, 2011). In Australia/New Zealand it is sufficient to notify the regulatory authority about using such a claim, which is also required when using approved claims (Food Standards Australia New Zealand, 2014). In the USA, where no requirements for nutrient or other function claims are listed, such notification is requested for claims on dietary supplements only (Food and Drug Administration, 2013). The authority can request to review the scientific substantiation of such a claim, but there is no official pre-marketing 
approval procedure in place (Food and Drug Administration, 2013; Food Standards Australia New Zealand, 2014).

In Argentina, Brazil and Russia, all nutrient function and other function claims have to be approved before use on a food product (Malla et al., 2013; Ministerio de Salud, 2011; Stringueta et al., 2012). This is a specific step in the licensing procedure for these so called 'health foods' in Russia (Global Agricultural Information Network, 2011b; Malla et al., 2013). Japanese legislation explicitly describes that nutrient function claims do not require pre-marketing approval, where all other function claims have to be approved before use on a product (Ministry of Health Labour and Welfare, Japan, 2015a, 2015b). The pre-marketing approval of other function claims in Japan is also part of a licensing system (Ministry of Health Labour and Welfare, Japan, 2015b). Legislation of Hong Kong, Mexico, South-Africa, Thailand, the Philippines and Vietnam does not describe a specific pre-marketing approval (Centre for Food Safety, 2008; Department of Health, 2010; Malla et al., 2013; Ministry of Health, 2013b; Ministry of Public Health, 1998; Secretaría de Economia, 2010).

Newly established disease risk reduction claims, which are not yet to be found in legislation or registers of the regulatory authority listing positively assessed claims, require pre-marketing approval by the regulatory authority in Australia/New Zealand, Barbados, Canada, Central America, Colombia, Ecuador, Europe, Indonesia, the Republic of Korea and the USA (Consejo de Ministros de Integración Económica Centroamericana, 2012; European Parliament and Council of the European Union, 2006: Food and Drug Administration, 2013; Food Standards Australia New Zealand, 2014; Global Agricultural Information Network, 2011a; Government of Canada, 2013; Ministerio de la Protección Social, 2008; Ministry of Food and Drug Safety, 2010; National Agency of Drug and Food Control, 2011; Republic of Ecuador, 2011b). In Argentina, Brazil, China, Japan and Singapore all disease risk reduction claims, including previously approved claims, require approval before going on the market (Agri-Food and Veterinary Authority of Singapore, 2015; Ministerio de Salud, 2011; Ministry of Health Labour and Welfare, Japan, 2015b; People's Republic of China, 1997; State Food and Drug Authority, 2005; Stringueta et al., 2012). In China, Japan and Singapore, obtaining approval to use a disease risk reduction claim is part of the licensing procedure for so called 'health foods' or 'functional foods' (Agri-Food and Veterinary Authority of Singapore, 2015; Ministry of Health Labour and Welfare, Japan, 2015b; People's Republic of China, 1997; State Food and Drug Authority, 2005). In China and Japan approved claims are found in registers of the regulatory authority, which in China lists the health relationships that can be used for claims which have yet to be approved (China Food and Drug Administration, 2015; Ministry of Health Labour and Welfare, Japan, 2015b). Notification of a disease-risk reduction claim is requested in the USA (Food and Drug Administration, 2013). Legislation of the Philippines does not define the authorisation procedure (Bureau of Food and Drugs, 1984).

The authorisation procedures across the different jurisdictions varies not only in using registers of approved claims or requesting pre-marketing approval, some pieces of legislation explicitly request or prohibit the use of product-specific claims. Product-specific statements (e.g. 'product $X$ helps to maintain normal bone density') imply that a specific food product which carries the claim has a positive physiological effect (Asp, 2002; Jew et al., 2008). The opposite type of claim is a generic statement (e.g. "contains calcium, which is needed for the maintenance of normal bone density'), based on scientific consensus on a diet-disease or diet-health relationship, which can be used on any product fulfilling specific compositional criteria (Asp, 2002; Jew et al., 2008). Table 3 outlines whether legislation is sufficiently defined to allow generic statements, product-specific statements or both.
All jurisdictions specifying whether product-specific or generic nutrition claims are allowed, require nutrition claims to be generic statements (Agri-Food and Veterinary Authority of Singapore, 2015; Bureau of Food and Drugs, 1984; Centre for Food Safety, 2008; European Parliament and Council of the European Union, 2006; Food and Drug Administration Taiwan, 2012; Food and Drug Administration, 2013; Food Standards Australia New Zealand, 2014; Global Agricultural Information Network, 2011b; Government of Canada, 2013; Ministry of Health, 2013a; Ministry of Public Health, 1998; Ohama et al., 2006; People's Republic of China, 2011; Stringueta et al., 2012). It is only in Singapore where product-specific claims are permitted next to generic claims (Malla et al., 2013).

Russia and Taiwan permit product-specific nutrient function claims and new nutrient function claims in the Republic of Korea are product-specific (Food and Drug Administration Taiwan, 2012; Kim et al., 2006; Malla et al., 2013). The other 12 jurisdictions describing the type of statement permitted authorise generic claims only (Agri-Food and Veterinary Authority of Singapore, 2015; Bureau of Food and Drugs, 1984; Centre for Food Safety, 2008; Consejo de Ministros de Integración Económica Centroamericana, 2012; European Parliament and Council of the European Union, 2006; Food and Drug Administration Taiwan, 2012; Food Standards Australia New Zealand, 2014; Government of Canada, 2013; Ministry of Public Health, 1998; Ohama et al., 2006; People's Republic of China, 2011; Stringueta et al., 2012).

Eight of the reviewed jurisdictions (viz. Australia/New Zealand, Brazil, Canada, Central America, EU, Malaysia, Singapore, The Philippines) approve the use of generic statements for other function claims (Agri-Food and Veterinary Authority of Singapore, 2015; Bureau of Food and Drugs, 1984; Consejo de Ministros de Integración Económica Centroamericana, 2012; European Parliament and Council of the European Union, 2006; Food Standards Australia New Zealand, 2014; Government of Canada, 2013; Ministry of Health, 2013a; Stringueta et al., 2012). The use of product-specific claims is allowed in China, Japan, Russia and Taiwan (Food and Drug Administration Taiwan, 2012; Malla et al., 2013; Ministry of Health Labour and Welfare, Japan, 2015b; People's Republic of China, 1997; State Food and Drug Authority, 2005). In the Republic of Korea, claims describing new health effects of nutrients are product-specific claims, whereas other function claims which are already approved for use are generic claims (Ministry of Food and Drug Safety, 2010).

Australia/New Zealand, Brazil, Canada, Europe, Singapore, the Philippines and the USA require disease risk reduction claims to be generic statements (Agri-Food and Veterinary Authority of Singapore, 2015; Bureau of Food and Drugs, 1984; European Parliament and Council of the European Union, 2006; Food and Drug Administration, 2013; Food Standards Australia New Zealand, 2014; Government of Canada, 2013; Stringueta et al., 2012). In the Republic of Korea the use of both product-specific and generic claims is allowed, again claims describing new health effects are treated as product-specific claims (Ministry of Food and Drug Safety, 2010). Product-specific reduction of disease risk claims are also permitted in China and Japan (Ministry of Health Labour and Welfare, Japan, 2015b; People's Republic of China, 1997).

\section{Emerging scientific evidence}

In the majority of jurisdictions studied, the legislation demands that a health claim must be based on generally accepted scientific evidence. However, in three of the evaluated jurisdictions, i.e. USA, Japan and the Republic of Korea, health claims based on a minority opinion in the scientific community are permitted. Allowing health claims to be based on such a minority opinion or so called 'graded 
Table 3

Generic and product-specific claims.

\begin{tabular}{|c|c|c|c|c|c|}
\hline & & neric claims & Product-specific claims & Not specified & Not allowed \\
\hline \multirow[t]{14}{*}{ Nutrition clain } & & Australia/New Zealand & Singapore & Argentina & \\
\hline & & Brazil & & Barbados & \\
\hline & & Canada & & Brunei Darussalam & \\
\hline & & China & & Central America $^{\mathrm{a}}$ & \\
\hline & & EU & & Chile & \\
\hline & & Hong Kong & & Colombia & \\
\hline & & Japan & & Ecuador & \\
\hline & & Malaysia & & India & \\
\hline & & Russia & & Indonesia & \\
\hline & & Singapore & & Mexico & \\
\hline & & Taiwan & & Nigeria & \\
\hline & & Thailand & & Republic of Korea & \\
\hline & & The Philippines & & South-Africa & \\
\hline & & USA & & Vietnam & \\
\hline \multirow[t]{30}{*}{ Health claim } & Nutrient function claim & Australia/New Zealand & Republic of Korea ${ }^{\mathrm{b}}$ & Argentina & Brunei Darussalam \\
\hline & & Brazil & Russia & Barbados & Nigeria \\
\hline & & Canada & Taiwan & Chile & \\
\hline & & Central America $^{a}$ & & Colombia & \\
\hline & & China & & Ecuador & \\
\hline & & EU & & India & \\
\hline & & Hong Kong & & Indonesia & \\
\hline & & Japan & & Mexico & \\
\hline & & Malaysia & & South-Africa & \\
\hline & & Singapore & & USA & \\
\hline & & Thailand & & Vietnam & \\
\hline & & The Philippines & & & \\
\hline & Other function claim & Australia/New Zealand Brazil & China & Argentina & Brunei Darussalam \\
\hline & & Canada & Japan & Barbados & Hong Kong \\
\hline & & Central America $^{a}$ & Republic of Korea ${ }^{b}$ & Chile & India \\
\hline & & EU & Russia & Colombia & Nigeria \\
\hline & & Malaysia & Taiwan & Ecuador & South-Africa \\
\hline & & Singapore & & Indonesia & Thailand \\
\hline & & The Philippines & & Mexico & Vietnam \\
\hline & & & & USA & \\
\hline & Reduction of disease risk claim & Australia/New Zealand & China & Argentina & Brunei Darussalam \\
\hline & & Brazil & Japan & Barbados Chile & Hong Kong \\
\hline & & Canada & Republic of Korea ${ }^{\mathrm{b}}$ & Colombia & India \\
\hline & & Central America ${ }^{a}$ & & Ecuador & Malaysia \\
\hline & & EU & & Indonesia & Mexico \\
\hline & & Singapore & & & Nigeria \\
\hline & & The Philippines & & & Russia \\
\hline & & USA & & & South-Africa Taiwan \\
\hline & & & & & Thailand \\
\hline & & & & & Vietnam \\
\hline
\end{tabular}

a Including Costa Rica, El Salvador, Guatamala, Honduras, Nicaragua.

b Only new health relationships are assessed as product-specific claims, existing/approved health relationships are generic.

evidence', grants the possibility to use emerging evidence on a health effect induced by a specific food product or component (U.S. Food and Drug Administration, 2003a). In the USA, emerging scientific evidence is allowed in the substantiation of disease risk reduction claims, which are called qualified or graded health claims (U.S. Food and Drug Administration, 2003b). The level of scientific evidence substantiating a health claim is indicated by a ranking system with the categories A, B, C and D. Category A may only be used for claims based on generally accepted scientific evidence, thereby reflecting the highest level of evidence. Categories B, C and D reflect the second, third and fourth level of scientific evidence (D resembling the weakest evidence), and claims must be accompanied by a disclaimer that the claimed effect is substantiated by a lower level of evidence (Hasler, 2008; Kavanaugh et al., 2007; U.S. Food and Drug Administration, 2003b). In Japan emerging scientific evidence can be used for other function claims, the so-called qualified FOSHU (Ministry of Health Labour and Welfare, Japan, 2015b). Qualified FOSHU can be approved for an ingredient when the efficacy of the ingredients is suggested but not established yet (Ministry of Health Labour and Welfare, Japan, 2015b; Ohama et al., 2006). The efficacy is considered to be suggested in different situations, e.g. when the mechanism of action is clear but no randomized controlled trial (RCT) has been performed or no significant effect was shown in an RCT; or when an RCT shows a significant effect without a clarified mechanism of action (Ohama et al., 2006). The statement 'evidence has not necessarily been established' must accompany such a claim (Yamada et al., 2008). Also in the Republic of Korea other function claims can be based on three levels of evidence: convincing, probable and insufficient evidence. The statements of claims based on probable and insufficient evidence must reflect the lower level of evidence for substantiation (Food and Drug Administration, 2007). In other jurisdictions, health claims are required to be based on generally accepted scientific evidence or so called consensus in the scientific community upon an effect of consuming an ingredient (e.g. (European Parliament and Council of the European Union, 2006; State Food and Drug Authority, 2005)). This requirement resembles the highest level of evidence or the ' $A$ ' rank in the USA.

\section{Discussion}

The growing interest in functional foods has led an increasing number of jurisdictions to propose policies and regulations dealing 
with these new products and the claims made on effects of these products, to assure both industry and consumer benefits (Lalor and Wall, 2011; Moors, 2012). Where the evaluated jurisdictions all require the claims to be based on scientific evidence, this paper focusses on the dissimilarities between the reviewed legislation. Differences are shown in the type of claims permitted, the authorisation procedure of claims and use of emerging scientific evidence to substantiate a claim.

\section{Types of claims}

As depicted in Table 1, the studied jurisdictions permit different types of claims. All reviewed legislation permits nutrition claims, where almost half of the jurisdictions do not permit the use of reduction of disease risk claims. Where most jurisdictions do not allow claims to directly refer to diseases, in Canada therapeutic claims are permitted (Malla et al., 2013). The types of claims permitted throughout the studied jurisdictions are relatively similar, although the definition sometimes differs, e.g. claims labelled as function claims in Canada are considered to be reduction of disease risk claims in other jurisdictions (Malla et al., 2013).In spite of the legal differentiation between the types of claims permitted, ranging from nutrition claims, nutrient function claims, other function claims and reduction of disease risk claims, consumers do not always seem to understand this division between claims. Not perceiving these differences between types of claims can be due to cultural differences between consumers, the personal relevance for the consumer, or the fact that all claims describe a link between health and nutrition and such information is processed similarly in the brain (Verbeke et al., 2009, 2010; Williams, 2005). Therefore the effect of legal differentiation between the types of claims, as permitted in all studied jurisdictions, can be questioned. Also the effects of prohibiting some claims (as reduction of disease risk claims) when permitting other types of claims can then be challenged. The Codex guidelines to permit nutrition and health claims are seen to be followed closely by newly developed legislation, for example the draft regulation on nutrition and health claims of India (Codex Committee on Food Labelling, 2013). Using Codex guidelines as a basis for legislation should lead to more international harmonisation (Codex Committee on Food Labelling, 2013; Jones et al., 2008). Various other reviewed jurisdictions (as Hong Kong and Thailand) mention following the guidelines, although it is not specified how these recommendations are taken into consideration in the legislative frameworks.

When the guidelines would describe not only the different types of claims with their conditions and recommendations for scientific substantiation, but also include suggestions for application procedures and communication strategies, even more international harmonisation could be attained.

\section{Authorisation procedures}

The studied jurisdictions have various authorisation procedures in place for the different types of claims (Table 2), although it is noticeable that not all evaluated jurisdictions explicitly define the authorisation procedures. When defined in legislation, it is shown that for health claims more often pre-market approval of especially newly defined relationships between intake and health outcomes is required. In most jurisdictions however, no approval process is defined for nutrition claims.

\section{Pre-marketing approval}

In most jurisdictions, the conditions which nutrition claims have to fulfil are listed, but no specific approval process to carry a claim on a food product is described. Only US and Chinese legislation explicitly state that no other relationships than the ones listed in specific legislation or registers of the regulatory authority can be used as nutrition claims.

In some jurisdictions nutrient function or other function claims explicitly do not require pre-marketing approval, where in other cases notification of a claim describing a new health effect is required (as in Australia/New Zealand). In most jurisdictions which approve the use of disease risk reduction claims, pre-marketing approval by the regulatory authority is required. Russia, China, Japan and Brazil are therein exceptions by requiring pre-marketing approval for various types of claims, even if similar types of claims are already permitted on the market. This is seen to go hand in hand with the use of a licensing system for functional foods or so called 'health foods' and often with the permission of using product-specific health claims on these products (Table 3 ). Only in Brazil permission is requested for generic claims as well.

When approval of a claim before marketing is requested, the scientific substantiation of a claim is assessed by a regulatory authority or on behalf of such an authority as in Europe by the European Food Safety Authority (EFSA) (European Parliament and Council of the European Union, 2006). However, in various jurisdictions not only the scientific substantiation of the claimed effect is considered, but also the safety and efficacy is taken into account. This is explicitly stated in the pieces of legislation of jurisdictions requiring licensing of a product, as in Russia and China. In the USA, the pre-marketing approval process and the need for evidence based on consensus to fully substantiate a claim was considered by the court in Pearson $v$. Shalala to be a violation of an industries' freedom of speech, leading to the possibility of using emerging evidence to substantiate a claim after the following Consumer Health Information for Better Nutrition Initiative in 2003 (Silverglade, 1996; U.S. Food and Drug Administration, 2003b). The issue of qualified health claims is further addressed in section 'Emerging scientific evidence'.

Requesting pre-marketing approval is seen to be more often required for claims that describe effects more directly related to health outcomes, as disease risk reduction claims. Evidence in literature suggests that claims which have a clearer link with health and preventing diseases are considered to be more persuasive to consumers (Katan, 2004; Silverglade, 1996; Verbeke et al., 2009). Therefore these claims are thought to have a stronger potential to mislead consumers when they are not sufficiently substantiated (Katan, 2004; Silverglade, 1996; Verbeke et al., 2009). As described in section 'Types of claims'. however, consumer research suggests that in spite of a legal differentiation between these claims, consumers are often not capable of differentiating between these various types of claims on food products (Hooker and Teratanavat, 2008; Verbeke et al., 2009; Verhagen et al., 2010; Williams, 2005). In addition, consumers do not seem to be aware of the approval process for claims prior to marketing, while such an assessment and approval of health claims by an independent organisation is requested by consumers (Gray, 2013). Also, American consumers are sceptical about the truthfulness of nutrition claims, even though these claims are pre-approved by the regulatory authority (DeVeau, 2012). Although the idea of a stricter approval procedure for claims with higher probability to result in consumer misleading when they are not sufficiently substantiated is understandable, the issues that consumers (i) do not distinguish between the different types of claims and (ii) are mostly unaware of the approval procedure, result in the question whether these stricter approval procedures for mostly other function claims and reduction of disease risk claims lead to higher consumer protection.

Another issue arising with the requirement for pre-marketing approval is the burden for both industry and authorities reviewing the proposed claim. Since the approval of a claim is highly uncertain and the substantiation procedure requires much time and 
resources, the industry has little incentives to request a claim (Bremmers et al., 2013; Coppens, 2007; de Boer and Bast, 2015; Hagenmeyer, 2006; Lalor and Wall, 2013). The competent authorities reviewing claims are shown to have difficulties processing all requests, as exemplified by both the situation in Europe as well as the USA: in Europe, the high amount of proposed claims $(>44.000)$ for EFSA to review, lead to a very slow assessment procedure due to an increased workload (Ernst and Young, 2012; Verhagen et al., 2010). The FDA pre-marketing approval process of nutrition claims in the USA is reduced to a 'policy of non-enforcement' (DeVeau, 2012).

\section{Positive list}

Several evaluated jurisdictions make list the permitted claims or the requirements for claims. The use of such a positive list could stimulate the use of these permitted claims, by giving a clear overview of which claims are permitted and how these claims should be used (Verhagen et al., 2010). However, the incentive for the industry to conduct research could be diminished as possibilities to make use of those already approved claims exists (Malla et al., 2013).

\section{Generic versus product-specific claims}

Many jurisdictions in this paper are shown to permit generic claims. Only in Russia, Japan, China, Taiwan, Republic of Korea and Singapore some product-specific claims are allowed on food products. In literature the use of generic claims is suggested to be disadvantageous for firms, since the approved claims can not only be used by the industrials performing the research; competitors are also able to use the claim on their product and thereby creating a free rider problem (Malla et al., 2013; Silverglade, 1996; Urala et al., 2003). Research on nutrition and health claim regulations suggest that using product-specific claims could protect against this free rider problem and could stimulate investments and expenditures on research and development (Malla et al., 2013; Urala et al., 2003). For consumers however it could be beneficial to permit the use of generic claims, so more food products will carry a claim and more potential health benefits are visible for consumers (Malla et al., 2013). Even though the scientific standard is similar for generic and product-specific claims, the type of evidence on which these claims are based can be different (Asp, 2002; Jew et al., 2008; Richardson et al., 2003). From a theoretical point of view, generic claims are based on generally accepted knowledge and therefore do not require additional studies proving the effect in a human setting, where product-specific claims need scientific substantiation from human intervention studies with the specific product (Asp and Bryngelsson, 2008; Asp, 2002; Jew et al., 2008). However, it is shown that in several jurisdictions as the EU, USA and Australia/New Zealand also generic claims require such human studies to substantiate a claim (Asp and Bryngelsson, 2008; Verhagen et al., 2010).

\section{Emerging scientific evidence}

Only three of the twenty-eight reviewed jurisdictions (Japan, the Republic of Korea and the United States of America) allow health claims to be based on emerging scientific evidence or the so-called minority opinion. All claims supported by such a lower level of substantiating evidence must reflect this by carrying some type of disclaimer. These graded health claims are permitted with a view to stimulating firms to perform research and accurately market the benefits of functional ingredients; and to help consumers prevent diseases and improve their health by making informed decisions based on accurate information (Crowe and Francis, 2013; Hooker and Teratanavat, 2008). For the industry, the approval of graded health claims decreases the length and strictness of the approval process (Hooker and Teratanavat, 2008). It gives the opportunity to get a product to market more quickly and thereby enhances the possibilities for food industries to grow and compete internationally (Hooker and Teratanavat, 2008; Lalor and Wall, 2011). However, the effect of graded health claims on consumers seems to be less positive: various studies show that consumers are not able to distinguish between the graded claims with qualifying language and health claims without qualifying language (Hasler, 2008; Hooker and Teratanavat, 2008; Kapsak et al., 2008; Lalor and Wall, 2011; Verhagen et al., 2010). It could therefore be interesting to focus on using emerging scientific evidence as substantiation for claims that influence a consumer's perception of health less directly, as is suggested for nutrition claims. Thereby emerging scientific evidence will have a lower probability to mislead consumers. Currently however this emerging evidence is only possible to be used in other function and disease risk reduction claims, claims which can be considered to have a larger effect on consumers since they are more directly related to health effects. Although the use of newly obtained scientific evidence could be beneficial for health by creating the opportunity to inform consumers about health benefits of certain products, consumers should be protected against misleading statements.

\section{Conclusion}

This paper reviews legislation on nutrition and health claims of 28 jurisdictions and puts these findings in a broader perspective by addressing consumer and industry issues. Several differences arise in the approach of the various pieces of legislation, with main differences found in (i) the types of nutrition and health claims permitted, (ii) the approval procedure of claims and (iii) the use of emerging scientific evidence.

Since the different types of nutrition and health claims permitted or prohibited in the various jurisdictions do not seem to elicit differing consumer responses according to consumer studies, it can be questioned whether a strict legal separation between the types of claims is required.The approval procedures related to these types of claims are seen to depend upon the use of a licensing system and the use of registers or lists with the permitted claims or requirements for claims published in either legislation or by regulatory bodies. In a licensing system often product-specific claims are permitted following pre-marketing approval, lists with requirements or approved claims often deal with generic statements. In most jurisdictions only claims which describe new relationships between intake of nutrients and a health effect, which have not been published on such lists or in any legislation, are subject to pre-marketing approval by the regulatory authority. The use of a positive list with permitted claims could increase the availability of claims on the market, because companies can easily use a claim from the permitted list on their product. This should be positive for consumers, since they are more exposed to health messages on products. The allowance of generic claims could stimulate the industry less than product-specific claims to innovate, since a company obtaining the claim is not the only one able to use it. However, it again could lead to an increased use and exposure of claims for consumers. The impact on innovation of these different types of claims should be reviewed to see which approach would have most positive effects. The need for pre-marketing approval is designed to protect consumers from misleading, by assuring the substantiation of a claim is generally accepted in the scientific community before the product is placed on the market. However, the process creates a high burden for industry and authorities reviewing substantiation which could be disproportionate for claims which are expected to have less effect on a consumers' 
willingness to buy. Although pre-marketing approval is in most jurisdictions more often required for claims more easily related to health (as other function or disease risk reduction claims), when consumers are not able to perceive differences between the various types of claims and do not realise that these claims are assessed upon their scientific evidence, the effect of such an approval process can be questioned. Therefore, not only more information is required upon the effects of the different types of claims on consumers, also the idea of pre-marketing approval should mainly be used when a false claim could have high impact on consumers, so when proposed health benefits have a high probability to result in a positive effect on health. From a scientific perspective, higher probability requires relatively more prove, whereas lower probability (with inherent a lower consumer misleading effect) would require less substantiation. This should be incorporated throughout the different jurisdictions. This is directly related to the use of emerging or graded evidence, which is suggested to be positive for industry, innovation and even consumers. The Japanese system is most transparent in the reasons for allowing specific evidence to substantiate a claim, still requesting some type of evidence to support the communicated effect. The use of emerging evidence is currently possible for other function and reduction of disease risk claims in legislation approving some kind of grading. However, this emerging evidence might be more suitable in the substantiating nutrition claims, since the possibility to mislead consumers could be less and innovation will still be simulated. At this moment however insufficient information is available on the effects on consumers of using emerging scientific evidence in communicating health benefits via claims.

The studied legislative documents show critical differences and although various approaches have positive points, no optimal approach to regulate nutrition and health claims has been implemented yet. Although more consumer research upon the perception of the different types of claims is required, it would be preferable to permit similar types of claims throughout jurisdictions, permit the use of emerging evidence for claims having a lower probability to mislead consumers (as nutrition claims) and to require pre-marketing approval of claims with higher impact. The efforts of the Codex Alimentarius Committee to internationally harmonise the handling of nutrition and health claims should be leading in all developments and improvements of legislation, to stimulate work of the industry in the field of functional foods and to enhance the opportunity for consumers to use health-enhancing products.

\section{References}

Agri-Food \& Veterinary Authority of Singapore, 2015. A Guide to Food Labelling and Advertisements. <http://www.ava.gov.sg/NR/rdonlyres/B96B0EC2-1D1E-4448 9C25-ABD8470D2BF4/26937|

AGuidetoFoodLabellingandAdvertisementsVersionSepte.pdf> (accessed April 2015).

Aschemann-Witzel, J., Hamm, U., 2010. Do consumers prefer foods with nutrition and health claims? Results of a purchase simulation. J. Mark. Commun. 16, 4758.

Asp, N.-G., 2002. Health claims within the Swedish Code. Generic claims and product-specific physiological claims in relation to current European and international developments. Scand. J. Nutr. 46, 131-136.

Asp, N.-G., Bryngelsson, S., 2008. Health claims in Europe: new legislation and PASSCLAIM for substantiation. J. Nutr. 138, 1210S-1215S

Baccino, F., 2012. Argentina's Case. Food labeling in Latin America: how far is the new boom region when it comes to its own national markets? <http://foodlawstrategies.wordpress.com/2012/07/09/argentinas-case-foodlabeling-in-latin-america-how-far-is-the-new-boom-region-when-itcomes-to-its-own-national-markets/> (accessed February 2014).

Bremmers, H.J., van der Meulen, B.M.J., Purnhagen, K., 2013. Multi-stakeholder responses to the European Union health claims requirements. J. Chain Netw. Sci. $13,161-172$

Bureau of Food and Drugs, 1984. Administrative Order No. 88-B s. 1984. Republic of the Philippines, Ministry of Health, Manila.
Centre for Food Safety, 2008. Technical Guidance on Nutrition Labelling and Nutrition Claims. Hong Kong Centre for Food Safety, Hong Kong.

Chan, P., 2011. Regulations and Guidelines Relating to Functional Foods in SouthEast Asia. ILSI India, New Delhi.

China Food and Drug Administration, 2015. 27 Categories of health functions claims approved by SFDA. <http://www.sfdachina.com/info/86-1.htm> (accessed April 2015).

Codex Committee on Food Labelling, 2013. Guidelines for Use of Nutrition and Health Claims (CAC/GL 23-1997). Codex Alimentarius, Rome.

Consejo de Ministros de Integración Económica Centroamericana, 2012. Reglamento Técnico Centroamericano RTCA 67.01.60:10 - Etiquetado Nutricional de Productos Alimenticios Preenvasados para Consumo Humano para la población a partir de 3 años de edad (unofficial translation).

Coppens, P., 2007. The impact of the nutrition and health claims regulation on the food industry. Eur. Food Feed Law Rev. 2007, 67-75.

Crowe, K.M., Francis, C., 2013. Position of the academy of nutrition and dietetics: functional foods. J. Acad. Nutr. Diet. 113, 1096-1103.

Da Silveira, T.F.V., de Mello Vianna, C.M., Mosegui, G.B.G., 2009. Brazilian legislation for functional foods and the interface with the legislation for other food and medicine classes: contradictions and omissions. Physis Rev. Saúde Coletiva 19, 1189-1202.

De Boer, A., Bast, A., 2015. Stakeholders' perception of the nutrition and health claim regulation. Int. J. Food Sci. Nutr. 1-8. http://dx.doi.org/10.3109/09637486. 2014.986071.

Department of Health, 2010. Regulations relating to the labelling and advertising of foodstuffs. Republic of South Africa, Cape Town.

DeVeau, T.M., 2012. Naturally confusing consumers: express federal preemption of state claims regarding false and misleading food product labels. Kentucky J. Equine, Agric. Nat. Resour. Law.

Diplock, A.T., Aggett, P.J., Ashwell, M., Bornet, F., Fern, E.B., Roberfroid, M.B., 1999. Scientific concepts in functional foods in Europe: consensus document. Br. J. Nutr. 81, S1-S28.

Ernst \& Young, 2012. External Evaluation of EFSA - Final Report.

Euromonitor International, 2015a. Fortified/Functional Packaged Food in the Netherlands.

Euromonitor International, 2015b. Fortified/Functional Packaged Food - Worldwide Historic Growth (2009-2014).

Euromonitor International, 2015c. Fortified/Functional Packaged Food - Worldwide Growth Forecast (2014-2019).

European Parliament and Council of the European Union, 2006. Regulation (EC) No. 1924/2006 of the European Parliament and of the council of 20 December 2006 on nutrition and health claims made on foods. Off. J. Eur. Union L 404 49, 9-25.

Food and Drug Administration, 2007. Regulation on Approval of Functional Ingredient for Health Functional Food. Republic of Korea, Seoul.

Food and Drug Administration, 2013. Code of Federal Regulations Title 21, Chapter 1 , Subchapter B - Food for Human Consumption. Federal Government of the United States, Washington DC.

Food and Drug Administration Taiwan, 2012. Regulations for Application of Health Food Permit. <https://consumer.fda.gov.tw/Law/Detail.aspx?nodeID=518\& lang=1\&lawid=160> (accessed April 2015).

Food Safety and Standards Authority of India, 2012. Draft "Regulation on Labelling (Claims)." Government of India, New Delhi.

Food Standards Australia New Zealand, 2014. Standard 1.2.7 Nutrition, Health and Related Claims. F2013L00054.

Gautier, C., 2012. Food Health Claims: Challenges for ASEAN Manufacturers. <http:// www.tilleke.com/resources/food-health-claims-challenges-asean-manufacturers> (accessed April 2015).

Giudice, C., 2013. Brazil works on new rules for functional and health claims. <http://www.eas.eu/News_Item/3023> (accessed November 2014).

Global Agricultural Information Network, 2011a. TCB1126 - Barbados Food and Agricultural Import Regulations and Standards - Narrative. United States Department of Agriculture Foreign Agricultural Service, Washington DC.

Global Agricultural Information Network, 2011b. RS1168 - Russian Federation Food and Agricultural Import Regulations and Standards - Narrative. United States Department of Agriculture Foreign Agricultural Service, Washington DC.

Global Agricultural Information Network, 2012. Nigeria Food and Agricultural Import Regulations and Standards - Narrative. United States Department of Agriculture Foreign Agricultural Service, Washington DC

Government of Canada, 2013. Food and Drug Regulations. Government of Canada, Ottawa.

Gray, N., 2013. Most consumers don't know what EFSA is, experts find. <http:// www.nutraingredients.com/Consumer-Trends/Most-consumers-don-t-knowwhat-EFSA-is-experts-find $>$ (accessed April 2015)

Hagenmeyer, M., 2006. Health Claims meet Bureaucracy. Eur. Food Feed Law Rev. 2006, 233-240.

Hasler, C.M., 2008. Health claims in the United States: an aid to the public or a source of confusion? J. Nutr. 138, 1216S-1220S.

Hawkes, C., 2004. Nutrition Labels and Health Claims: The Global Regulatory Environment. World Health Organization, Geneva.

Health Canada, 2015. Health Claim Assessments. <http://hc-sc.gc.ca/fn-an/labeletiquet/claims-reclam/assess-evalu/index-eng.php> (accessed April 2015).

Hooker, N.H., Teratanavat, R., 2008. Dissecting qualified health claims: evidence from experimental studies. Crit. Rev. Food Sci. Nutr. 48, 160-176.

Howlett, J., 2008. Functional Foods: From Science to Health and Claims. ILSI Europe, Brussels. 
Jew, S., Vanstone, C.A., Antoine, J.-M., Jones, P.J.H., 2008. Generic and productspecific health claim processes for functional foods across global jurisdictions. J. Nutr. 138, 1228S-1236S.

Jones, P.J.H., Asp, N.-G., Silva, P., 2008. Evidence for health claims on foods: how much is enough? Introduction and general remarks. J. Nutr. 138, 1189S-1191S.

Kapsak, W.R., Schmidt, D., Childs, N.M., Meunier, J., White, C., 2008. Consumer perceptions of graded, graphic and text label presentations for qualified health claims. Crit. Rev. Food Sci. Nutr. 48, 248-256.

Katan, M.B., 2004. Health claims for functional foods: regulations vary between countries and often permit vague claims. Br. Med. J. 328, 180.

Kavanaugh, C.J., Trumbo, P.R., Ellwood, K.C., 2007. The US Food and Drug Administration's evidence-based review for qualified health claims: tomatoes, lycopene, and cancer. J. Natl Cancer Inst. 99, 1074-1085.

Kim, J.Y., Kim, D.B., Lee, H.J., 2006. Regulations on health/functional foods in Korea. Toxicology 221, 112-118.

Kwak, N., Jukes, D.J., 2000. Current international approaches to food claims. Nutr. Rev. 58, 370-377.

Lalor, F., Wall, P.G., 2011. Health claims regulations: Comparison between USA, Japan and European Union. Br. Food J. 113, 298-313.

Lalor, F., Wall, P.G., 2013. Making and justifying health claims. Int. J. Dairy Technol. $66,321-324$.

Malla, S., Hobbs, J.E., Sogah, E.K., 2013. Functional Foods and Natural Health Products Regulations in Canada and Around the World: Nutrition Labels and Health Claims. Saskatchewan.

Ministerio de la Protección Social, 2008. Resolucion 288 (unofficial translation). Government of Colombia, Bogotá.

Ministerio de Salud, 2011. Disposición No. 7730 (unofficial translation). Government of Argentina, Buenos Aires.

Ministry of Agriculture, Agricultural and Livestock Service, 2006. Food Law Chile Title II Food (II): Labelling and Advertising (unofficial translation). Republic of Chile, Santiago.

Ministry of Food and Drug Safety, 2010. Health Functional Foods Act. Republic of Korea, Seoul.

Ministry of Food and Drug Safety, 2011. Food Sanitation Act. Republic of Korea, Seoul.

Ministry of Health, 2001. Public Health (Food) Act. Negera Brunei Darussalam Government, Brunei Darussalam.

Ministry of Health, 2013a. Malaysian Dietary Guidelines - Key Message 14. Federal Government Malaysia, Putrajaya.

Ministry of Health, 2013b. Circular on the advertisements for the foods under the management of the Ministry of Health.

Ministry of Health Labour and Welfare, Japan, 2015a. Food with Nutrient Function Claims (FNFC). <http://www.mhlw.go.jp/english/topics/foodsafety/fhc/01. html> (accessed April 2015).

Ministry of Health Labour and Welfare, Japan, 2015b. Food for Specified Health Uses (FOSHU). <http://www.mhlw.go.jp/english/topics/foodsafety/fhc/02.html> (accessed April 2015).

Ministry of Health Labour and Welfare, Japan, 2015c. Food with Health Claims, Food for Special Dietary Uses, and Nutrition Labeling. <http://www.mhlw.go.jp/ english/topics/foodsafety/fhc/> (accessed April 2015).

Ministry of Public Health, 1998. Notification of the Ministry of Public Health. Re: Nutrition Labelling. Government of Thailand, Bangkok.

Moors, E.H.M., 2012. Functional foods: regulation and innovations in the EU. Innovation 25, 424-440.
National Agency for Food and Drug Administration and Control, 2005. Pre-Packaged Food (Labelling) Regulations.

National Agency of Drug and Food Control, 2011. Regulation HK.03.1.23.11.11.09909 (2011) on the Control of Claims on Processed Food Labeling and Advertisements. HK.03.1.23.11.11.09909.

Ohama, H., Ikeda, H., Moriyama, H., 2006. Health foods and foods with health claims in Japan. Toxicology 221, 95-111.

People's Republic of China, 1997. Health Food Standard (Functional Foods) (GB 16740-1997)

People's Republic of China, 2011. National Food Safety Standard for nutiriton labelling of prepackaged foods (GB 28050-2011).

Public Health and Municipal Services Ordinance, 2008. Food and drugs (composition and labelling) regulation 2008. Hong Kong Government, Hong Kong.

Republic of Ecuador, 2011a. Rotulado de productos alimenticios para consumo humano. Parte 2. Rotulado nutricional. Requisitos (unofficial translation).

Republic of Ecuador, 2011b. Rotulado de productos alimenticios para consumo humano. Parte 3. Requisitos para declaraciones nutricionales y declaraciones saludables (unofficial translation)

Richardson, D.P., Affertsholt, T., Asp, N.-G., Bruce, Å., Grossklaus, R., Howlett, J., Pannemans, D., Ross, R., Verhagen, H., Viechtbauer, V., 2003. PASSCLAIMSynthesis and review of existing processes. Eur. J. Nutr. 42, 96-111.

Secretaría de Economia, 2010. Mexican Official Norm NOM-051-SCFI/SSA1-2010 (unofficial translation). Federal government of Mexico, Mexico City.

Silverglade, B.A., 1996. The Nutrition Labeling and Education Act: Progress to date and challenges for the future. J. Public Policy Mark. 15, 148-150.

State Food and Drug Authority, 2005. Interim Regulations on the Registration of Health Foods (SFDA Regulation; Order No. 19).

Stringueta, P.C., do Amaral, M. da P.H., Brumano, L.P., Pereira, M.C.S., de Oliveira Pinto, M.A., 2012. Public Health Policies and Functional Property Claims for Food in Brazil.

U.S. Food and Drug Administration, 2003a. Claims That Can Be Made for Conventional Foods and Dietary Supplements. <http://www.fda.gov/Food/ IngredientsPackagingLabeling/LabelingNutrition/ucm111447.htm> (accessed April 2015).

U.S. Food and Drug Administration, 2003b. Consumer Health Information for Better Nutrition Initiative: Task Force Final Report. <http://www.fda.gov/Food/ IngredientsPackagingLabeling/LabelingNutrition/ucm096010.htm> (accessed April 2015).

Urala, N., Arvola, A., Lähteenmäki, L., 2003. Strength of health-related claims and their perceived advantage. Int. J. Food Sci. Technol. 38, 815-826.

Verbeke, W., Scholderer, J., Lähteenmäki, L., 2009. Consumer appeal of nutrition and health claims in three existing product concepts. Appetite 52, 684-692.

Verhagen, H., Vos, E., Francl, S., Heinonen, M., van Loveren, H., 2010. Status of nutrition and health claims in Europe. Arch. Biochem. Biophys. 501, 6-15.

Williams, P., 2005. Consumer understanding and use of health claims for foods Nutr. Rev. 63, 256-264.

Yamada, K., Sato-Mito, N., Nagata, J., Umegaki, K., 2008. Health claim evidence requirements in Japan. J. Nutr. 138, 1192S-1198S.

Zawistowski, J., 2011. Legislation of functional foods in Asia. In: Saarela, M. (Ed.), Functional Foods - Concept to Product. Woodhead Publishing, Cambridge, pp. 73-108. 